\title{
Design and Build Educational Game "New Normal"
}

\author{
Felicia Kusuma $^{1}$, Ridwan Sanjaya ${ }^{2}$, Erdhi Widyarto Nugroho ${ }^{3}$ \\ 1,2,3 Department of Information Systems, Faculty of Computer Science \\ Soegijapranata Catholic University, Semarang, Indonesia \\ 1'zomiigame@gmail.com, ${ }^{2}$ ridwan@unika.ac.id, ${ }^{3}$ erdhi@unika.ac.id
}

\begin{abstract}
Indonesia's first confirmed case of COVID-19 infection was in early March 2020. Of course, the citizens in Indonesia want this pandemic to end soon. The fact is, there are plenty of people who do not apply the health protocols properly in daily life. Therefore, the effort to formulate the educational media in the form of a game will be carried out in this study. "New Normal" game is an educational media about how to apply the health protocols properly that have a nice user interface design so that the players will not get bored easily while playing. Thus, the knowledge about the importance of applying the health protocols properly will be embedded in every player's mind.
\end{abstract}

Keywords - educational game, educational media, health protocols application, new normal.

\section{INTRODUCTION}

Indonesia first confirmed cases of COVID-19 infection was in early March 2020. The widespread of COVID-19 in Indonesia affected many sectors, for example, the health sector which was overwhelmed by the increased number of patients, and also the economic sector which had a major impact on Indonesia itself [1].

Of course, as Indonesians we want the COVID-19 pandemic to end soon. In fact, in daily life, there are plenty of people who forget to wear masks, lower their masks, and do not apply the health protocols properly. Many people don't understand the dangers of COVID-19 spread and don't understand the benefits of implementing the health protocols [2].

Therefore, the efforts to formulate educational media in the form of a game regarding the application of health protocols during the pandemic will be carried out in this study. As the result, players will understand and remember the importance of implementing the health protocols, such as wearing masks properly, washing hands with soap, doing physical distancing, staying away from crowds, and limiting mobilization and interaction.

This educational media must be able to be interesting in the form of an exciting game that has an attractive appearance so that players do not feel bored easily playing it. Thus, the knowledge of the importance of implementing the health protocols will be embedded in the minds of the players.

Other educational games with the new normal theme have been available in the Google Play Store, one of which is a game from Educa Studio called "Marble New Habits - New Normal". This game is prioritized for children, so in this game, there is no written play tutorial, instead, the directions are in the form of audio-visual interaction, and guidance from parents is also needed. This game teaches guidelines for living a new normal life such as how to wash hands properly, create masks and how to wear masks and do physical distancing in various locations such as zoos, malls, supermarkets, and others. This game is intended for children, so it only provides education with fewer competition elements. Meanwhile, in the "New Normal" game, which is the project of this report, all elements of the health protocols are included in it, and there is competition in the form of a high score. In addition, this game is not only aimed at educating, but also provides challenging and fun mini-games so that it can be played in free times. Because the challenges in this game are quite difficult 
and there are a lot of readings, this game is intended for generation $\mathrm{Y}$ and generation $\mathrm{Z}$ who are more understanding of technology and like challenges.

\section{LITERATURE}

\subsection{Literature Review}

"New Normal" game is an educational media based on Android that educates how to apply the health protocols properly. This game has some fun and interesting minigames, also has a nice user interface, so as a result, the player will not be bored easily playing it. The main software for making this game is Construct 2, CorelDRAW, Adobe Photoshop, and Clip Studio Paint. Knowledge about applying health protocols in the new normal era is also needed.

\subsection{Definition of Educational Games}

Educational games are one type of media that serves to provide knowledge to users through a game [3]. Educational games are one type of media that is not boring to maintain some knowledge and provide some lessons to its players [4].

\subsection{Definition of Educational Media}

Educational media is a tool that serves to convey part or all of a learning program that may be difficult to explain verbally. Educational media are usually in the form of learning materials, practice questions, games, and others [5].

\subsection{Definition of New Normal}

New normal is a new lifestyle that must be done to continue to carry out activities as usual during the pandemic by implementing health protocols [10]. The health protocols referred to here are using masks, washing hands, doing physical distancing, staying away from crowds, and reducing mobility [11].

\section{RESEARCH METHODOLOGY}

\subsection{Research Flow}

The research process begins by thinking about the initial concept of the game first, then sketching to realize the design of the game's interface and game system into a rough drawing along with an explanation in each image as shown in Figure 3.1. Then, through the rough sketch of the image, the creation of assets in the game begins.

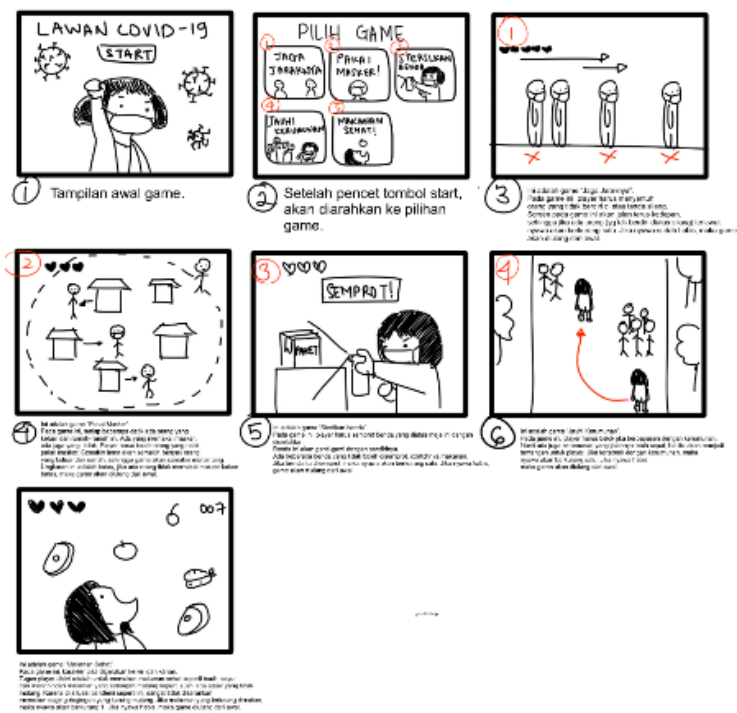

Figure: 3.1 The rough design sketch of the "New Normal" game

After all the game assets have been created, the next thing to do is to create a user interface as shown in Figure 3.1 in the Construct 2 software, then create the logic for setting events for each layout in the game project. After the game creation is complete, the game is built into an APK so that it can be played on Android devices.

After the game has become an APK, the game is distributed to several android users who are willing to provide constructive criticism and suggestions for the sake of the game's quality improvement.

After the criticism and suggestions have been collected, several game systems are refined according to the complaints that were submitted by the android users who have played the game.

After the game is perfect and does not require further improvement, this game can already be used as research material.

\section{RESULTS AND DISCUSSION}

\subsection{Mini-game "Keep the Distance"}

This mini-game has the settings in the mall. So many people queued to pay for their groceries at the cashier. During the era of the 
COVID-19 pandemic, we should keep our distance from other people to prevent the spread of the virus. So, the rule of this game is that the player must tap on the people who don't stand above the blue sign. Figure 4.1 below is the user interface of the mini-game "Keep the Distance".

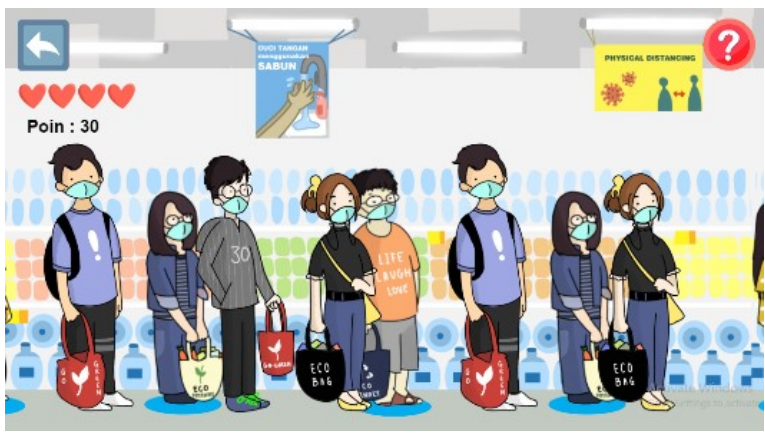

Figure: 4.1 Mini-game "Keep the Distance"

\subsection{Mini-game "Wear the Mask"}

This game has the settings in a residential complex. Many people leave their homes to fulfill their own needs. In this era of the COVID-19 pandemic, we must always wear masks outside the house. So, the rule of this game is, the player must tap on the person who is not wearing the mask properly, and don't let people with no mask pass the yellow border. Figure 4.2 below is the user interface of the mini-game "Wear the Mask".

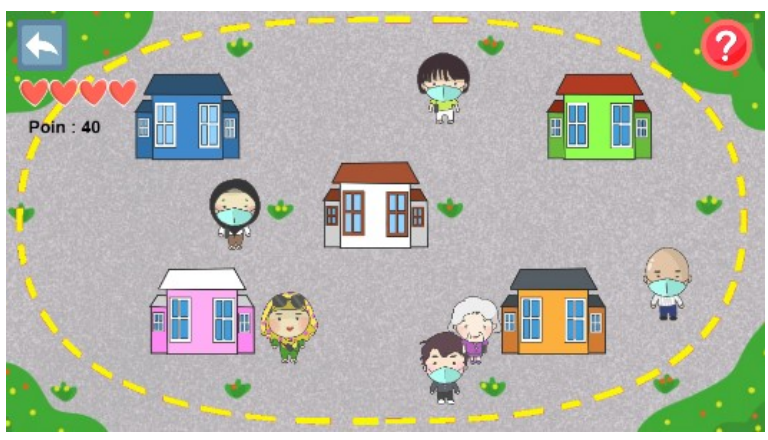

Figure 4.2: Mini-game "Wear the Mask"

\subsection{Mini-game "Sterilize Things"}

This game has the settings in the house. In this game, there is a table on which there will be items that change randomly. The rule in this game is, the player must spray all the items, except foods. Figure 4.3 below is the user interface of the mini-game "Sterilize Things".

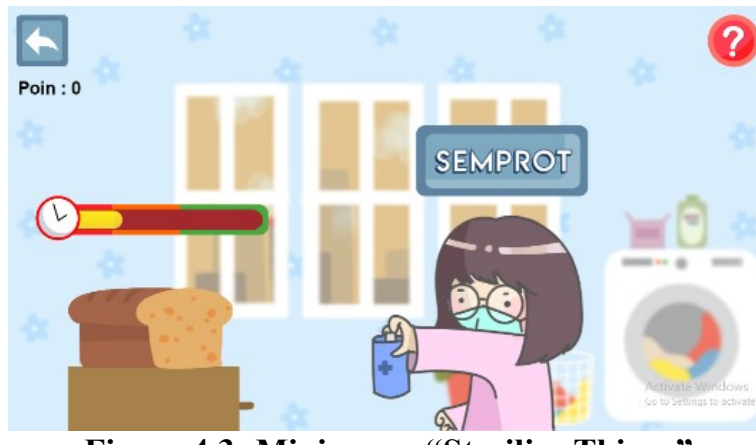

Figure 4.3: Mini-game "Sterilize Things"

\subsection{Mini-game "Avoid Crowds"}

This game has settings in the crowded traditional market. In this era of the COVID19 pandemic, we must keep our distance from other people. The rule of this game is to avoid colliding with people by pressing the left and right buttons to move Marie. Figure 4.4 below is the user interface of the minigame "Avoid Crowds".

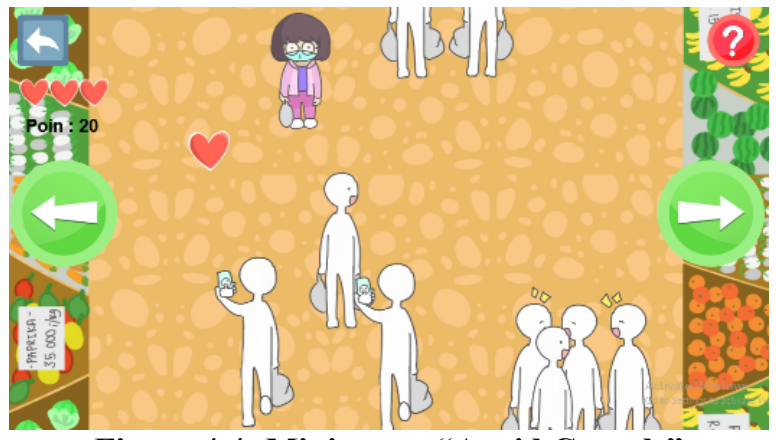

Figure 4.4: Mini-game "Avoid Crowds"

\subsection{Mini-game "Healthy Food"}

This game has the settings inside the house. In this era of COVID-19, we must not eat the half-done foods, so the rule of this game is to avoid Marie eating the half-done food like medium-rare steak and sushi by pressing the left and right button to move Marie. Figure 4.5 below is the user interface of the mini-game "Healthy Food".

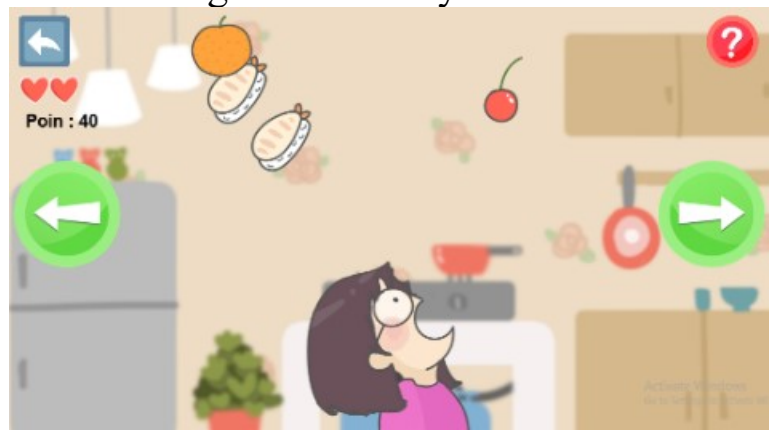

Figure 4.5: Mini-game "Healthy Food" 


\subsection{Mini-game "Limiting Mobility"}

This game has settings inside the crowded roadway. In this era of COVID-19, we should travel outside the home only if necessary, so the rule of this game is to tap a car that wants to go to a public place like a swimming pool and entertainment area, and don't tap the car that has a necessary. Figure 4.6 below is the user interface of the minigame "Limiting Mobility".

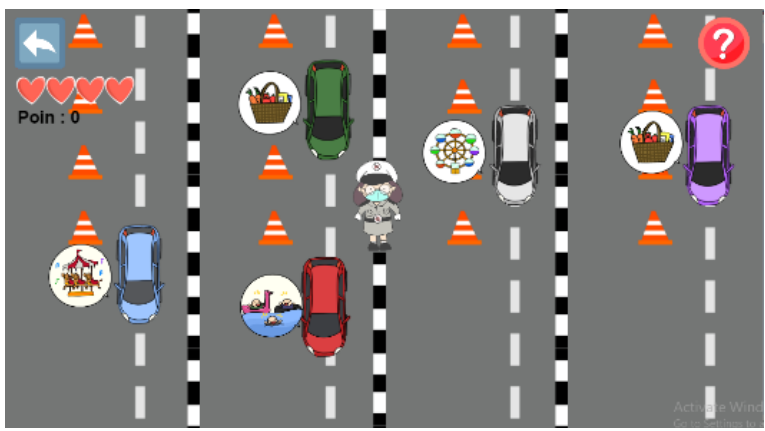

Figure 4.6: Mini-game "Limiting Mobility"

\subsection{Respondent's Profile}

\section{a. Respondent's Current Educational Status}

Figure 4.7 below showed that most respondents were from college student education status reaching 34 respondents, while respondents with high school education status were 23 out of 81 people, and respondents with undergraduate education status were 24 respondents out of a total of 81 respondents.

Status Pendidikan Sekarang

81 responses

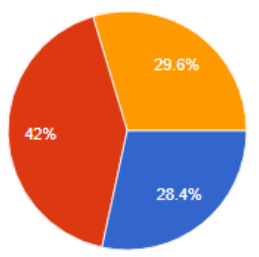

- SMA/SMK

- Mahasisw - Sarjana

Figure 4.7: Education Status Percentage

\section{b. Respondent's Gender}

Figure 4.8 below showed that most respondents were male respondents, with a total of 43 respondents from 81 respondents, while the female respondents amounted to 38 respondents from 81 respondents.

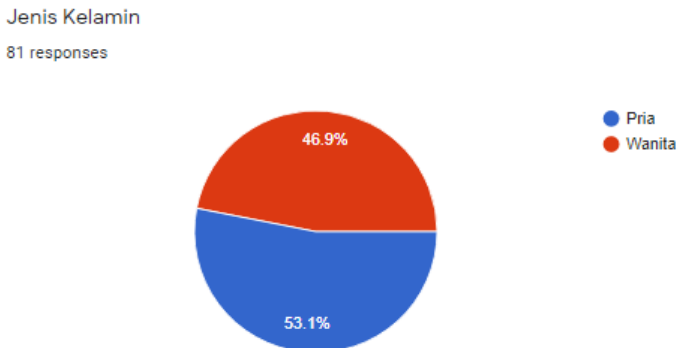

Figure 4.8: Gender Percentage

\subsection{SPSS Reliability Test}

Table 4.1 below showed that PE variable has questionable internal consistency, EE variable has a good internal consistency, HM variable has an acceptable internal consistency and BI variable has excellent internal consistency.

Table 4.1: Reliability Test Result

\begin{tabular}{ccc}
\hline Variable & $\begin{array}{c}\text { Cronbach's } \\
\text { Alpha }\end{array}$ & $\begin{array}{c}\text { Internal } \\
\text { Consistency }\end{array}$ \\
\hline $\mathbf{P E}$ & 0.666 & Questionable \\
\hline $\mathbf{E E}$ & 0.880 & Good \\
\hline $\mathbf{H M}$ & 0.716 & Acceptable \\
\hline BI & 0.917 & Excellent
\end{tabular}

\subsection{SPSS Correlations Test}

Table 4.2 below is the result of the correlation test. Correlated data is marked with a significant value (2-tailed) which has a smaller value than 0.05 , so it can be concluded that:

a. PE correlates with $\mathrm{BI}$ with a significant value less than 0.05 and is marked with an asterisk.

b. EE correlates with BI with a significant value less than 0.05 and is marked with an asterisk.

c. HM correlates with BI with a significant value less than 0.05 and is marked with an asterisk. 
Table 4.2: Correlations Test Result

\begin{tabular}{|c|c|c|c|c|c|}
\hline \multicolumn{6}{|c|}{ Correlations } \\
\hline & & SPE & SEE & SHM & SBI \\
\hline \multirow[t]{3}{*}{ SPE } & Pearson Correlation & 1 & $.316^{\star \star}$ & $.424^{n \pi}$ & $.510^{\mathrm{k}}$ \\
\hline & Sig. (2-tailed) & & .004 & .000 & .000 \\
\hline & N & 81 & 81 & 81 & 81 \\
\hline \multirow[t]{3}{*}{ SEE } & Pearson Correlation & $.316^{\star \pi}$ & 1 & $.584^{N *}$ & $.492^{\star \star}$ \\
\hline & Sig. (2-tailed) & .004 & & .000 & .000 \\
\hline & $\mathrm{N}$ & 81 & 81 & 81 & 81 \\
\hline \multirow[t]{3}{*}{ SHM } & Pearson Correlation & $.424^{\mathrm{N}}$ & $.584^{n \pi}$ & 1 & $.728^{\star \star}$ \\
\hline & Sig. (2-tailed) & .000 & .000 & & .000 \\
\hline & $\mathrm{N}$ & 81 & 81 & 81 & 81 \\
\hline \multirow[t]{3}{*}{ SBI } & Pearson Correlation & $.510^{\star \pi}$ & $.492^{n \pi}$ & $.728^{\star *}$ & 1 \\
\hline & Sig. (2-tailed) & .000 & .000 & .000 & \\
\hline & $\mathrm{N}$ & 81 & 81 & 81 & 81 \\
\hline
\end{tabular}

\section{CONCLUSION}

In order to make "New Normal" games to be interesting for generation $\mathrm{Y}$ and generation $\mathrm{Z}$ is to make exciting challenges so that players don't get bored easily playing those mini-games. In addition to exciting challenges, the game will be even more interesting if it has good and cute art, besides the simple flow of the game will certainly make it easier for players to understand the flow and how the game works.

To formulate the difficulty of each minigame is by providing different challenges in each mini-game, other than that, each minigame is given clear instructions to play so that players can easily understand how to play the game.

To translate the "New Normal" game into Construct 2-based software is by arranging events and action logics in the event sheet for each layout.

\section{REFERENCES}

[1] U. R. Akbar and S. Humaedi, "The Role of CSR in Efforts to Overcome the COVID-19 Pandemic" (Peran CSR dalam Upaya Mengatasi Pandemi COVID-19), Pros. Penelit. dan Pengabdi. Kpd. Masy., vol. 7, no. 2, 2020, doi: 10.24198/jppm.v7i2.28874 http://journal.unpad.ac.id/prosiding/arti cle/view/28874

[2] R. K. Sari, "Identification of the Causes of Citizens' Non-compliance with the Implementation of $3 \mathrm{M}$ Health Protocols During the COVID-19 Pandemic" (Identifikasi Penyebab Ketidakpatuhan Warga Terhadap Penerapan Protokol Kesehatan 3M di Masa Pandemi COVID-19), J. AKRAB JUARA, vol. 6 , no. 1, 2021.

https://akrabjuara.com/index.php/akrab juara/article/view/1354

[3] D. A. Amanda and A. R. Putri, "Development of Educational Games for Mathematics Subjects on Flat Shapes based on Android at SDN 1 Jepun" (Pengembangan Game Edukasi Pada Mata Pelajaran Matematika Materi Bangun Datar Berbasis Android di SDN 1 Jepun), JOEICT (Jurnal Educ. Inf. Commun. Technol., vol. 3, no. 2, pp. 160-168, 2019.

https://jurnal.stkippgritulungagung.ac.i $\mathrm{d} /$ index.php/joeict/article/view/1241

[4] A.R. Christianti, R. Sanjaya, and C. Murniati, "Developing Educational Game for Collaborative Learning", Proc. of International Seminar on Application for Technology of Information and Communication (ISemantic), p. 1-6, 2016, doi: 10.1109/ISEMANTIC.2016.7873800.

https://jtiik.ub.ac.id/index.php/jtiik/arti cle/view/1671

[5] BaliMobi, "Android Based Educational Media" (Media Edukasi Berbasis Android), 2015. https://www.balimobi.com/blog/mediaedukasi-berbasis-android.html (accessed Apr. 03, 2021).

https://www.balimobi.com/blog/mediaedukasi-berbasis-android.html

[6] M. N. Aly et al., "A Safe Guide to 'New Normal' Facing the Covid-19 Pandemic" (Panduan Aman 'New Normal' Menghadapi Pandemi Covid19), J. Layanan Masy. (Journal Public Serv., vol. 4, no. 2, p. 415, 2020, doi: 10.20473/jlm.v4i2.2020.415-422.

https://ejournal.unair.ac.id/jlm/article/view/234 72 
[7] A. Rosidi and E. Nurcahyo, "Application of the New Normal in Handling Covid-19 as a Pandemic in Positive Law" (Penerapan New Normal/Kenormalan Baru Dalam Penanganan Covid-19 sebagai Pandemi Dalam Hukum Positif), NASPA J., vol. 42, no. 4, p. 1, 2020. https://jurnal.ugr.ac.id/index.php/jir/arti cle/view/288 